IIIIIIIIIIIIIIIIIIIIIIIII

シンポジア

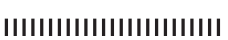

\title{
第33 回農薬残留分析研究会
}

\author{
日時：平成22年 10 月 4 日（月），5日（火） \\ 会場 : 千葉市文化センター（千葉市）他 \\ 主催：日本農薬学会 農薬残留分析研究会
}

（2012年1月6日受理）

第33回農薬残留分析研究会は, 特別幹事として元日本農 薬学会長の安部浩東京農工大学名誉教授に加わって頂き，千 葉県千葉市の千葉市文化センター他で開催された。

第1日目には2題のシンポジウム講演と特別講演，ポス ターセッション（24題）および「農薬残留分析におけるLCMS/MS 分析の問題点とそのソリューション」というテーマ での分析機器メーカー 4 社によるセッションを行った。 今回 から新しい取り組みとして, ポスター発表に対し参加者によ る投票と研究会委員の協議により, 優秀な発表を選定し表彰 した.

第2日目は, ポスター発表の中から研究会幹事が選定した 6 課題について口頭発表を実施した。午後からは，エクス カーションとして千葉県内の研究施設などを視察した.

今回の研究会には, 250 名を超える参加者が全国各地から 集まり, 講演会場ならびにポスターおよび展示会場は大盛況 であった．以下に開催内容の概略を記す。

\section{シンポジウム I：食品に残留する農薬等の公示試験法の開発 について}

根本 了氏（国立医薬品食品衛生研究所）より，「食品に 残留する農薬等の公示試験法」,「残留農薬等試験法検討実施 要領について」および「加工食品中の残留農薬等試験法の開 発について」といった3つの主な内容で講演があった。

まず，「告示試験法」と「通知試験法」が現行の公示試験 法であることが紹介され, 農薬等の登録から残留基準值設定 の流れを踏まえたうえで, その実施要領が詳細に示された。 試験法として, 試料採取から抽出溶媒, 各種精製方法, 測定 という流れの他, 全般的な事項として留意すべき内容に至る 解説がされた. 添加回収試験については別途まとめて, 評価 方法, 添加濃度, 定量限界の考え方や留意事項について解説
が及んだ。

さらに最新のトピックスとして, 加工農食品中の残留農薬 等試験法の開発について解説された. 中国産冷凍餃子の事件 に端を発し, 平成20年には厚生労働省が検討会を設置し, まずはメタミドホスに代表される「有機リン系農薬試験法」 の確立が進められた. その後, 「加工食品試験法I」と「加工 食品試験法II」の開発経緯が説明された。すなわち, 定量限 界目標值は $0.1 \mathrm{ppm} と し$, 高濃度に残留している農薬等を迅 速に分析することを目的とした「加工食品試験法I」と，一 律基準の $0.01 \mathrm{ppm}$ を定量限界とし残留基準値への適合性を 確認するための試験法として「加工食品試験法 II」と位置づ けて, 試験法確立を進めている.この目的の違いにより「加 工食品試験法 $\mathrm{I} 」$ は毒性が高く検出頻度の高い農薬約 330 品 目を検討対象農薬としており, 現在, $3 つ の$ 公設研究機関で 検討を進めている。一方「加工食品試験法I」は, 通知一斉 試験法をべースに分析可能な農薬などについて優先的に検討 を進めている. 対象食品としては, 輸入量が多い食品や代表 的な食品を選択している. 加工食品は, 植物性であるか動物 性であるかといった特性で8つの分類に分け，それぞれにつ いて適切な試験法を組み合わせている. 試験法は基本的に GC-MS とLC-MSに扔ける測定で，7つにグループ分けてい る. 検討の中間報告として, 冷凍餃子を対象食品とした試験 法について紹介された.

両加工食品試験法について平成 21 年以降の計画が示され, 課題として, 農薬検出時の対応, 原材料にまで原因が遡れな い場合の対応および不検出農薬の取り扱いなどが示された。 また両試験方法の運用面では, 目的や適用範囲などからの試 験法の選択基準の明確化が課題とされていることが紹介され た. 


\section{シンポジウムII：食品中残留農薬の規制と摂取量調査}

永山敏廣氏（東京都健康安全研究センター）より,「食事 からの農薬摂取に関する知っておきたい用語」,「食品中残留

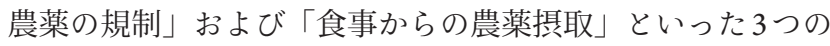
主な内容で講演があった。

「食事からの農薬摂取に関する知っておきたい用語」では, 食品中の農薬を含む毒性をもつ物質との係わりで, 広く用い られている用語の語彙説明がされた。「危険性」を示す用語 では, リスクとハザードの違い,「摂取許容量」では, ADI, TDI, ARfD おょび安全係数や無毒性量などが解説された. 「残留基準」ではMRL と農薬残留基準, 「暴露評価」では理 論最大一日摂取量と推定一日摂取量といったように類似した 用語を対比させて解説された。「摂取量調査」では, トータ ルダイエットスタディの調査方法として，マーケットバス ケット方式と陰膳（かげぜん）方式について解説された。 「安全性確保の考え方」として「リスク分析」が紹介され, 「リスク評価」、「リスク管理」，そしてそ机らを繋ぐ「リスク コミュニケーション」で分析されることが紹介された。

「食品中残留農薬の規制」では, 農産物に残留する農薬を 規制する2つの法律である「農薬取締法」と「食品衛生法」 の解説からスタートした．残留する可能性がある以上，人の 健康を損なうことがないようにする目的で残留基準が設定さ れていることから, 安全性を確保するための設定方法が示さ れた。また，ポジティブリスト制度の導入で変化した規制， それを監視する体制，違反した場合の指導体制なども紹介さ れた。

「食事からの農薬摂取」では, 摂取量調査の目的が健康リ スクを解析して, リスク管理措置の効果検証であることが示 された後,「マーケットバスケット方式」と「陰膳方式」に ついて詳細な説明がされ，その利点と留意点が紹介された。 さらに平成 3 年度から平成 16 年度に実施された摂取量調査 の結果について解説がされた。検出された農薬についても $\mathrm{ADI}$ と比較して十分低い比率であり，これらの結果は厚生 労働省のHPでも閲覧でき，その安全性が記載されているこ とが解説された。

\section{特別講演：千葉県における植物防疫の取り組み}

植松清次氏（千葉県農林総合研究センター）より, 1990 年代になって推進された「環境負荷低減に配慮した持続型農 業」といった課題について, 千葉県で取り組んできた植物防 疫技術開発の歴史について紹介された。

千葉県でも1993年から研究が始まり，2002年には「ちば エコ農業」推進事業が開始された。これに伴い千葉県におけ る農薬使用量は $30 \%$ 以上の減少といった成果を得ている.

「ちばエコ農業」の目的は, 慣行並みの収量・品質を維持 しつつ, 化学合成農薬や化学肥料を $50 \%$ 以上削減し, 環境 負荷を低減できる栽培技術を実証することとされている。こ
れらについて全 24 課題を設定して取り組んできた。「減化学 合成農薬栽培技術」では, 「土壌還元消毒法」による線虫防 除, 耕種的防除法による除草剂削減, 天敵（オオメカメム シ）によるコナジラミ防除，環境改善によるきゅうり褐斑病 防除などが挙げられる。千葉県の特産物である梨, きゅう り,トマトなどでは, PCシステムを用いた普及所と生産者 の連携やハウス管理で農薬散布量の削減も実施してきた。ゴ ルフ場管理では, 1990年に無農薬化を推進しており, 芝草 管理技術の開発を進めている。 すなわち, 耐病性品種の育 成，葉腐病（ラージパッチ）の防除対策などである.

土壌病害への取り組としては, カラ一疫病菌への抵抗性品 種育成, 炭疽病の無病親株いちごのリレー苗を北海道で栽培 して導入するといった生産システムで生産量を増やしてき た.さらに, 土壌還元消毒法や低濃度エタノール消毒によ り，実績も積み上げてきたことが紹介された。

\section{メーカーセッション}

近年, 残留農薬分析において急激にその利用場面が増えて きたLC-MS/MSに対し, 研究会としてもテーマとして取り 上げた. 今回の研究会の柱のひとつともいえる講演（全 4 題）となった. なお, メーカーセッションの題名は以下に示 す.

1. 「LC/MS分析における問題点とその解決法」滝埜昌彦 （アジレント・テクノロジー株式会社）

2.「LC/MS/MSライブラリを用いた残留農薬自動スクリー ニングについて」濱坂友子（サーモフィッシャーサイエ ンティフィック株式会社）

3.「LC-APCI-MS/MSを用いた残留農薬分析におけるイオ ンサプレッションの回避法」小梶哲雄（株式会社エー ビー・サイエックス)

4.「農薬残留分析に扔けるLC-MS/MS分析の問題点とその ソリューション」佐藤信武（日本ウォーターズ株式会 社）

\section{ポスターセッション}

研究会のメインで所謂「一般講演」に相当するポスター セッションは計 24 題が発表された. 2 日目の午前中には, 開 催幹事が選定した 6 題について口頭発表が実施された。

今回から, 残留農薬分析研究者の育成および優秀な研究の 論文投稿推進を目的としてベストポスター賞（最優秀賞 1 題, 優秀賞 2 題, 委員会特別賞 1 題）の表彰を実施した。発 表内容 (新規性, 重要性など) と発表方法（ポスター構成や 発表者解説の良さ）を基準として参加者 1 名が 1 票を投票す る形式を取り, 最優秀賞 1 題, 優秀賞 2 題は, 得票数の多い ものから選定し, 委員会特別賞 1 題は, それら得票結果を踏 まえて研究会委員が別途選定した発表に贈られた。

最優秀賞は「農作物への残留性に関するGLP試験におけ 


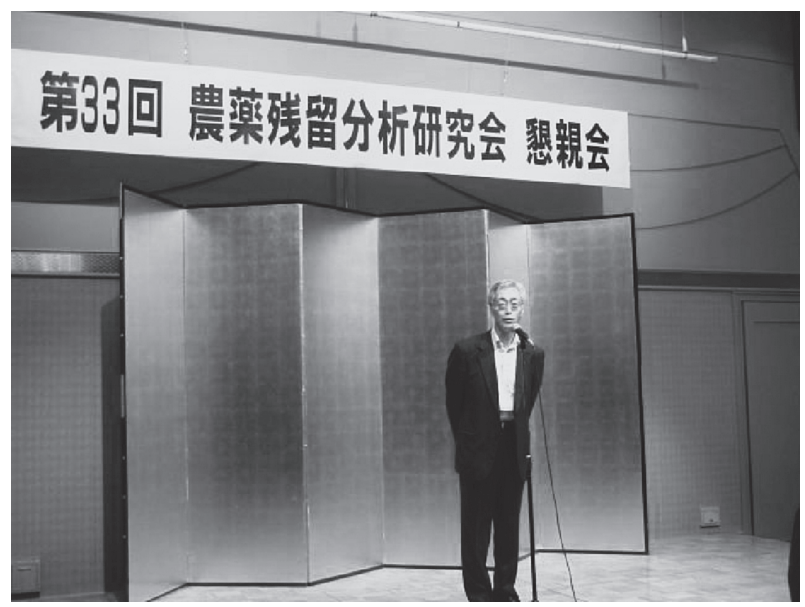

写真 1. 小松一裕委員長による挨拶

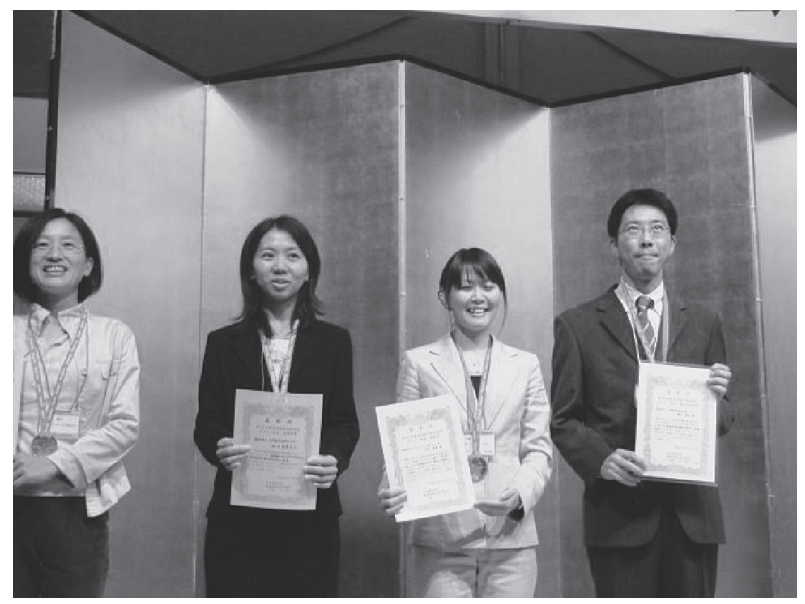

写真2. ポスター賞受賞をされた方々
る複数場所試験の実施例」湯川清子氏（住化テクノサービス 株式会社)，優秀賞は「振とう条件の違いによる塩析効果と 農薬の挙動について」谷澤春奈氏（株式会社アイスティサイ エンス）および「殺菌剤オキシテトラサイクリンの作物残留 分析法の改良」水口恵美子氏（財団法人日本食品分析セン ター), 委員会特別賞は「ブロッコリーにおける個体別残留 農薬濃度の変動について」藤田眞弘氏（財団法人残留農薬研 究所）が受賞した.

なお，ポスターセッションの全題名は以下に示す.

1.「残留農薬検查用ELISA キットに対して作物抽出液が 与える影響について」天野昭子（岐阜県農業技術セン ター)

2.「河川中の高魚毒性農薬迅速分析法」吉田達雄, 飛野敏 明（熊本県保健環境科学研究所）

3.「飼料中のヒドロキシイソキサゾール（ヒメキサゾー ル）分析法の検討」渡邊文子，水越一史，薮崎 隆， 中村宗知（財団法人日本食品分析センター）

4. 「農作物への残留性に関するGLP試験における複数場 所試験の実施例」湯川清子, 長澤 悟（住化テク， サービス株式会社）

5. 「農薬が残留した実農産物を原材料とする認証標準物質 の開発」鎗田 孝, 大竹貴光，伊藤信靖，青柳嘉枝， 黒田陽子，沼田雅彦（産業技術総合研究所計量標準総 合センター)

6.「残留農薬分析に必要な測定機器について：アンケート 集計結果」坂真智子 (財団法人残留農薬研究所化学部)

7.「ダイズ中有機リン系農薬及びピレスロイド系農薬分析 における加圧流体抽出法の適用」鎗田 孝, 青柳嘉枝, 大竹貴光（産業技術総合研究所計量標準総合センター）

8.「高速高圧抽出装置を用いた玄米試料中残留農薬の抽出 効率の検討」坂真智子，狛由紀子，今井真紀，佐藤 清（財団法人残留農薬研究所）
9.「振とう条件の違いによる塩析効果と農薬の挙動につい て」谷澤春奈，佐々野僚一（株式会社アイスティサイ エンス)

10.「QuEChERS法における妨害物質除去の試み」山下和 之(バリアン・テクノロジーズ・ジャパン・リミテッ ド)

11.「LC/MS-MSを用いた高マトリックス試料中農薬のイ オン化制御の検討」滝埜昌彦（アジレント・テクノロ ジー株式会社)

12.「TraceFinderソフトウェアを用いた農薬一斉分析」 濱坂友子, 山岸陽子 (サーモフィッシャーサイエン ティフィック株式会社）

13.「LC/MS/MSを用いた蒸気圧の高い農薬の簡便な分析 法の検討」手銭良太郎，山崎真央，三浦賢祐，前原由 紀江，大坪祥人，大坪茂樹，林 正博（日本エコテッ ク株式会社大阪分析センター), 西澤秀男（信頼性保証 グループ)

14.「LC-MSによる畜水産食品中スピノサドの分析」大野 春香, 上野英二, 渡邊美奈恵, 大島晴美, 三上栄一 (愛知県衛生研究所), 根本了, 松田りえ子（国立医 薬品食品衛生研究所)

15.「殺菌剤オキシテトラサイクリンの作物残留分析法の改 良」水口恵美子, 高橋賢司, 小沼千夏, 北原由美, 薮 崎 隆，中村宗知（財団法人日本食品分析センター）

16.「ネオニコチノイド系殺虫剤ジノテフラン測定用イムノ アッセイの農産物スクリーニング検査への適用可能性」 渡辺栄喜, 馬場浩司（農業環境技術研究所）, 三宅司郎 （堀場製作所）

17. 「Residual Characteristics of Insecticide Flonicamid and its Metabolites, TFNG and TFNA in Sweet Pepper」 Yong-Duk Jin, Hye-Young Kwon, Kyeong-Ae Son, Geon-Jae Im, Moo-Ki Hong (Chemical Safety Div., Na- 
tional Academy of Agricultural Science)

18.「ベンチアバリカルブイソプロピルの分析法および後作 物残留性の検討」高橋香隆, 菅野淳夫, 池田光政（ク ミアイ化学工業株式会社生物科学研究所）

19.「クロラントラニリプロールの後作物残留性調査」杉本 佐和子*, 藤田由紀*, 西村 隆**, 松澤幸一郎**, 飯島和昭*, 佐藤 清* (*財団法人残留農薬研究所, **株式会社化学分析コンサルタント)

20.「安定同位体を用いた残留農薬の迅速分析法」長澤 悟 （住化テクノサービス株式会社），瀧本善之（元住化テ クノサービス株式会社）

21.「多機能GPCクリーンアップシステムを用いた食肉お よび食肉加工品中の残留農薬分析」山本新也（豊橋市 衛生試験所・金沢大学大学院医学系研究科), 近藤裕 一, 鈴木 勝（豊橋市衛生試験所），本島雅昭，墨岡成 治, 藤岡正信（豊橋市保健所）, 宮本謙一（金沢大学大 学院医学系研究科)

22.「LC-MS/MSによるグリホサートおよびその代謝物の 土壌残留分析法」中村直紀，奥野潤一，権田重雄，小 田中芳次（財団法人日本植物調節剂研究協会研究所）

23.「茶中の農薬残留に関する実態調査（その 2)」烏蘭参 丹, 大村聖子，福原美代子（株式会社テクノスルガ・ ラボ)

24.「ブロッコリーにおける個体別残留農薬濃度の変動につ いて」藤田眞弘, 矢島智成, 浜野浩子, 飯島和昭, 佐 藤 清 (財団法人残留農薬研究所化学部)

\section{エクスカーション}

2日目は，午前中の口頭発表で研究会は閉会した。午後か ら50名ほどの希望者によるエクスカーションが実施され， 開催地である千葉県内の研究機関（「JA全農ちば 営農技術 センター」,「千葉県農林総合研究センター落花生試験地」) を訪問した。

\section{おわりに (謝辞)}

開催期間を通じて機器展示を実施頂いた，株式会社アイス ティサイエンス, アジレント・テクノロジー株式会社, 株式 会社エービー・サイエックス, エス・ジー・イージャパン株 式会社, 一般財団法人化学物質評価研究機構, 関東化学株式 会社, サーモフィッシャーサイエンティフィック株式会社, ジーエルサイエンス株式会社, 株式会社島津製作所, 日本 ウォーターズ株式会社, 日本電子株式会社, 日本ビュッヒ株 式会社, 林純薬工業株式会社, ブルカー・ダルトニクス株式 会社の関係者各位に感謝します.

開会中は，特産品の販売も行って頂いた「JA全農ちば」 の関係者各位，スタッフや会場整理を実施頂いた日本食品分 析センター, 化学分析コンサルタント, そして, 千葉県農林 総合研究センターの皆様に厚く御礼申しあげます.

そのほか，あらゆる面からサポート頂いた日本農薬学会農 薬残留分析研究会関係者各位および参加者の皆様に御礼申し 上げます。

（開催幹事：丸 諭, 山本幸洋, 藪崎 隆, 島村裕二，安部 浩) 